\title{
Epidemiological Study of Medicolegal Organophosphorus Poisoning in Central Region of Nepal
}

\author{
Amarnath Mishra ${ }^{1 *}$, Shukla $\mathrm{SK}^{2}$, Yadav $\mathrm{MK}^{3}$ and Gupta $\mathrm{AK}^{1}$
}

${ }^{1}$ Department of Forensic Science, Sam Higginbottom Institute of Agriculture, Technology \& Sciences, Deemed to be University, Allahabad, India

${ }^{2}$ Central Forensic Science Laboratory, Chandigarh, India

${ }^{3}$ Department of Community Medicine, National Medical College and Teaching Hospital, Birgunj, Nepal

\begin{abstract}
Organophosphorus (OP) pesticide self-poisoning is an important clinical problem in rural regions of the developing world. OP compounds are chemical compounds containing carbon-phosphorus bonds, primarily used in pest control and are often persistent organic pollutants. They are easily accessible, thus they are a commonly associated with suicides and accidental poisoning in Nepal.

In present study one hundred and seventy one patients with severe OP poisoning were admitted in the emergency ward of National Medical College and Teaching Hospital and Narayani Sub-Regional Hospital, Birgunj, Nepal from January 2010 to December 2011, were studied for a detailed epidemiological and medicolegal analysis.

The mean age group was 28 years, was prone to most of the cases. Most of the admitted cases were of suicidal as well as accidental in nature and women were the main victim than children. Suicidal deaths due to ingestion of OP compound are very common in Nepal, especially in women. The reason may be the increasing stress in the family and economic constraints. Accidental deaths due to occupational exposure or inhalation of OP compounds are reported but in these cases mortality rate is less than that suicidal poisoning. Further study should be needed by government and national and international NGO to evaluate it.
\end{abstract}

Keywords: Organophosphorus; Acute poisoning; Nepal; Carbonphosphorus; Manner of death

\section{Introduction}

Organophosphorus (OP) compounds are used as pesticides, herbicides, and chemical warfare agents in the form of nerve gases [1]. Acute poisoning by these agents is a major global problem with thousands of deaths occurring every year [2]. Most of the OP pesticides poisoning and subsequent death occur in developing countries following a deliberate self ingestion particularly in young, productive age group as highly toxic pesticides are readily available at the moment of stress due to family problem, failure in love and exam phobia [3]. Poisoning has been a common cause of medical admissions and deaths in Nepalese hospitals [4-11]. Accidental poisoning occurs every year in children due to their innovative and exploratory nature. Occupational exposure is also recorded due to unprotected use of pesticides during cultivation in Nepal and in other developing countries.

Self-harm has often been thought as a problem particular to the industrialized world. Recent work however begins to emphasize it importance in developing world. The global burden of study is reported that 5,93,000 people killed themselves in the developing world during $1990,75 \%$ of the world wide death from self harm [12-14].

A recent study demonstrated that $44 \%$ of all deaths almost amongst 10-50 year old woman in Bangladesh were due to poisoning the majority following suicidal ingestion of pesticides [15].

Pesticides poisoning from occupational, accidental and intentional exposure is a major developing world health problem [16]. Millions of people are exposed to danger by hazardous occupational practices and unsafe storage [17]. However it is the deliberate self poisoning that causes the great majority of the deaths and the immense strain the pesticides put on hospital services particularly Asia $[18,19]$.

In contrast, accidental and occupational exposures were estimated to cause 1 million cases with 200,000 deaths. Many studies have shown the deliberate self poisoning has for higher mortality than accidental poisoning. Various isolated hospital based studies also clearly demonstrate that $\mathrm{OP}$ compounds occupy the greatest burden of poisoning related morbidity and mortality in Nepal [20].

\section{Materials and Methods}

In this study 171 cases of organic phosphorus (OP) intoxication in the Narayani zone of Central region of Nepal were investigated. Patient with OP intoxication admitted to emergency department of National Medical College and Teaching Hospital (NMCTH) and Narayani SubRegional Hospital (NSRH), Birgunj, Nepal during January 2010 to December 2011. This prospective cohort study includes 72 male (M) and 99 female (F) consecutive patient history of ingestion, inhalation, availability of bottles, clinical symptoms and signs help to diagnose the OP poisoning.

Garlic- like smell was an added clinical sign in ingested sulphur containing OP poisoning. Analytical identification of OP compound in gastric aspirate or its metabolites in the body fluids gave the clue that patient has been exposed to OP compounds.

Usually the level of plasma (pseudo) cholinesterase drops to less than $50 \%$ before signs and symptoms. The age, sex, occupation, marital

${ }^{*}$ Corresponding author: Amarnath Mishra, Research Scholar, Department of Forensic Science, Sam Higginbottom Institute of Agriculture, Technology \& Sciences, Allahabad, India, Tel: +91-9454977836; E-mail: anmishra4u@gmail.com

Received July 31, 2012; Accepted September 27, 2012; Published September 29, 2012

Citation: Mishra A, Shukla SK, Yadav MK, Gupta AK (2012) Epidemiological Study of Medicolegal Organophosphorus Poisoning in Central Region of Nepal. J Forensic Res 3:167. doi:10.4172/2157-7145.1000167

Copyright: (C) 2012 Mishra A, et al. This is an open-access article distributed unde the terms of the Creative Commons Attribution License, which permits unrestricted use, distribution, and reproduction in any medium, provided the original author and source are credited. 
status, residential area, season, reason of poisoning, OP compounds involved, time of exposure or administration, time elapsed between administration of OP poison and admission to the hospital, duration of hospital stay, need for assisted ventilation, cardiac manifestation at the time of presentation, and during the in-hospital stay were recorded.

\section{Results and Discussion}

Table 1 and figure 1 describe that out of total 171 studied cases females were dominant with $57.89 \%$, this observation was very similar to previous researchers [19-25]. In Nepal females are main working group both inside and outside home, hence prone for stress and unhealthy routine that is the main reason for increasing the cases day by day.

Table 2 and figure 2 depict that OP poisoning was very common in age group of $16-30$ years $(51.46 \%)$ followed by $31-45$ years $(24.56 \%)$. The reason may be that this is the main working age group i.e.1630years, have the whole responsibility of their family and also heavy exposer to OP compounds due to working in cultivated area.

Table 3 and figure 3 describe occupation of patient. In 171 numbers of cases 17 patients were student who had taken the OP compounds due to failure in love and exam phobia. Farmers were exposed due to unprotected cultivation. Other victims consumed OP compounds due to family and financial weakness.

Table 4 and figure 4 describe marital status of patients. It is also

\begin{tabular}{|c|c|c|}
\hline Sex & No. of patients & $\%$ \\
\hline Male & 72 & 42.11 \\
\hline Female & 99 & 57.89 \\
\hline Total & 171 & 100 \\
\hline
\end{tabular}

Table 1: Total no. of OP poisoning victims with Sex distribution.

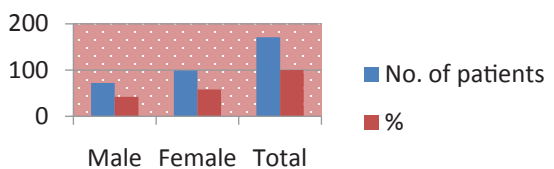

Figure 1: Total no. of OP poisoning victims with Sex distribution.

\begin{tabular}{|c|c|c|}
\hline Age & No. of victims & $\%$ \\
\hline $\mathbf{0 - 1 5}$ & 17 & 9.94 \\
\hline $\mathbf{1 6 - 3 0}$ & 88 & 51.46 \\
\hline $\mathbf{3 1 - 4 5}$ & 42 & 24.56 \\
\hline $\mathbf{4 6 - 6 0}$ & 19 & 11.11 \\
\hline $\mathbf{6 1 - 7 5}$ & 5 & 2.92 \\
\hline Total & 171 & 100 \\
\hline
\end{tabular}

Table 2: Age distribution amongst victims of OP poisoning.

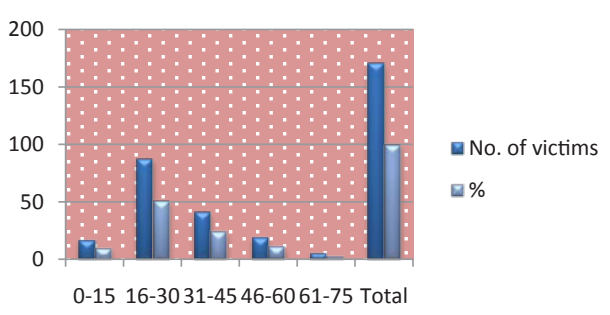

Figure 2: Age distribution amongst victims of $\mathrm{OP}$ poisoning. plays an important role in manner of death. Psychologically, married people have more family and financial constraints. So, majority of suicidal cases were due to these problems. Other typical problem like male members of family was working far from home or in other countries like Saudi, Gulf countries or in neighbor countries for good earnings. So, females came in stress and depressed by other family problems which are main cause of suicidal attempt and homicidal cases.

Table 5 and figure 5 describe year wise distribution of cases which is found in NMCTH and NSRH. There were less numbers of OP poisoning cases reported in NMCTH than that NSRH in 2010. But, this ratio increased in 2011.

Table 6 and figure 6 describe that most of the victims of OP poisoning from rural areas. In rural areas, accidental as well as suicidal poisoning has prominent. Main reason for Suicidal poisoning was due to family and economic constraints and accidental poisoning due to unprotected use of pesticides during cultivation. In other hand in urban areas, OP poisoning cases was due to incapability of arranged basic requirements and busy stressful life style. Homicidal poisoning cases were also noted in both urban as well as in rural areas.

Table 7 and figure 7 describe the seasonal variation of the incidence of OP poisoning was very large in the month during April to June

\begin{tabular}{|c|c|c|}
\hline Occupation & No. of victims & $\%$ \\
\hline Student & 17 & 9.94 \\
\hline Farmer & 94 & 54.97 \\
\hline Private job & 14 & 8.19 \\
\hline Own business & 23 & 13.45 \\
\hline Other & 23 & 13.45 \\
\hline Total & 171 & 100 \\
\hline
\end{tabular}

Table 3: Occupation wise distribution of victims of OP poisoning

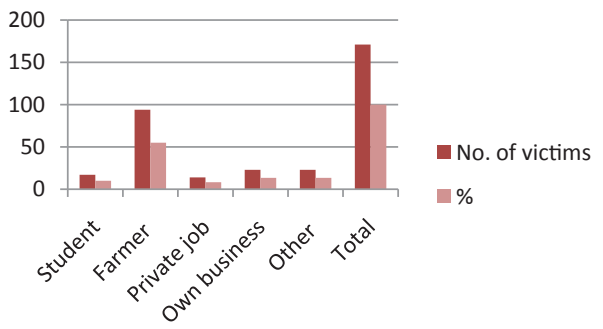

Figure 3: Occupation wise distribution of victims of OP poisoning

\begin{tabular}{|c|c|c|}
\hline Marital status & No. of patients & $\%$ \\
\hline Married & 121 & 70.76 \\
\hline Unmarried & 50 & 29.24 \\
\hline Total & 171 & 100 \\
\hline
\end{tabular}

Table 4: Marital status amongst victims of OP poisoning

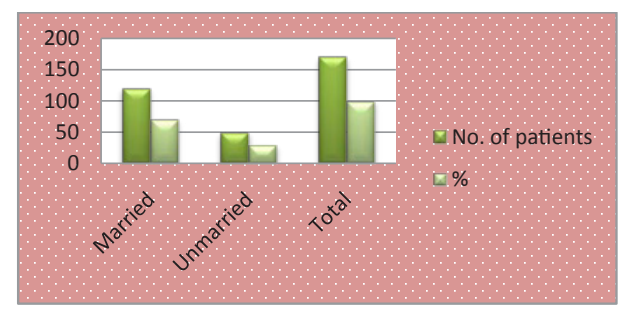

Figure 4: Marital status amongst victims of OP poisoning 


\begin{tabular}{|c|c|c|}
\hline Year & No. of patients & $\%$ \\
\hline $\mathbf{2 0 1 0}$ & 83 & 48.54 \\
\hline $\mathbf{2 0 1 1}$ & 88 & 51.46 \\
\hline Total & 171 & 100 \\
\hline
\end{tabular}

Table 5: Year wise distribution of OP poisoning cases.

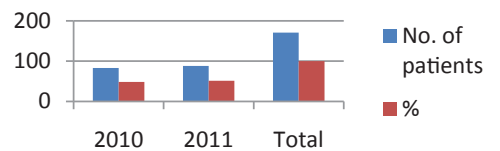

Figure 5: Year wise distribution of OP poisoning cases.

\begin{tabular}{|c|c|c|}
\hline Area & No. of patients & $\%$ \\
\hline Rural & 100 & 58.48 \\
\hline Urban & 71 & 41.52 \\
\hline Total & 171 & 100 \\
\hline
\end{tabular}

Table 6: Area wise distribution of OP poisoning cases.

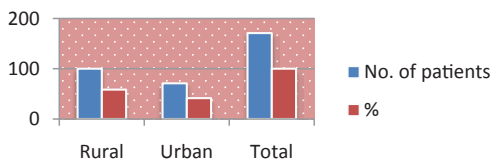

Figure 6: Area wise distribution of OP poisoning cases.

\begin{tabular}{|c|c|c|}
\hline Season & No. of patients & $\%$ \\
\hline January-March & 29 & 16.96 \\
\hline April-June & 58 & 33.92 \\
\hline July-September & 53 & 30.99 \\
\hline October-December & 31 & 18.13 \\
\hline Total & 71 & 100 \\
\hline
\end{tabular}

Table 7: Seasonal variation in incidences of OP poisoning.

and July to September (64.91\%), in these months harvesting is more; the major insecticide used in field and its main constituents was OP compounds. Therefore, due to the easy availability of the compound, poisoning incidence increases.

Table 8 and figure 8 describe socio-economic status of patients/ victims. It categorized in upper, middle and lower class. Numbers of victims of $\mathrm{OP}$ poisoning cases were belonging from lower and middle class.

Table 9 and figure 9 describe the types of different OP compounds consumed by patient. As per availability and use of different OP compounds in Nepal, incidence of poisoning by those insecticides is seen commonly. Metacid (Methyl parathion) showed highest consumption $52.05 \%$. Methyl parathion is generally used by farmers during harvesting season and stored in their houses. Majority of people is farmer in Nepal, as we know Nepal is a country of natural resources and field of cultivation.

From table 10 and figure 10, it is clear that due to mental, social and personal problems and easy availability of OP compounds in Nepal, India and other countries incidences of $\mathrm{OP}$ poisoning seen commonly.

Table 11 describes quantity of poison consumed and outcome of cases from history, clinical features and evaluation it was seen that 11$100 \mathrm{ml}$ of OP compounds had been taken by patient. In 171 cases of OP poisoning, $18.71 \%$ victims died and $81.29 \%$ victims recovered after administration of OP compounds. Methyl parathion and dichlorovos (DDVP) used as main source of OP poisoning.
Table 12 and figure 11 describe time interval between consumption of poison and hospital admission. Increase of time interval depends on nature of poisoning, distance of hospitals from place of occurrence of OP poisoning.

Table 13 and figure 12 describe common clinical features had seen in patients. On the basis of clinical features and history of victims of OP poisoning, doctors had treated the patients.

Table 14 and figure 13 clearly indicated that the victims of OP poisoning used it for suicidal purpose $(n=122) .32$ homicidal cases were recorded. 17 cases were recorded as accidental poisoning of OP compounds. It is clear from above table- suicidal deaths $>$ homicidal deaths $>$ accidental deaths. Homicidal cases had seen in cases of extramarital affairs, dowry demand and other family constraints.

\section{Conclusion}

Excessive use of Organophosphorus pesticides for agricultural purposes were intentional to harm not only our agriculture production but it's directly and indirectly affect to common people, due to easy availability in Nepal. It does not use only in agricultural practices but use as homicidal and suicidal purposes also. With the increasing stress in life, suicide among adolescents and young adults is a common problem. Females are the main working mass in the Nepalese society and face more stress during daily activities in comparative male. So,

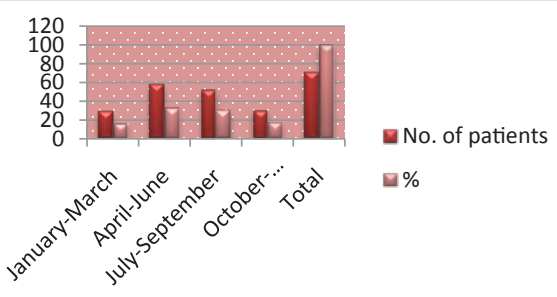

Figure 7: Seasonal variation in incidences of OP poisoning.

\begin{tabular}{|c|c|c|}
\hline Category & No. of patients & $\%$ \\
\hline Upper class & 12 & 7.02 \\
\hline Middle class & 71 & 41.52 \\
\hline Lower class & 88 & 51.46 \\
\hline Total & 171 & 100 \\
\hline
\end{tabular}

Table 8: Socio-economic (SE) status of victims of OP poisoning.

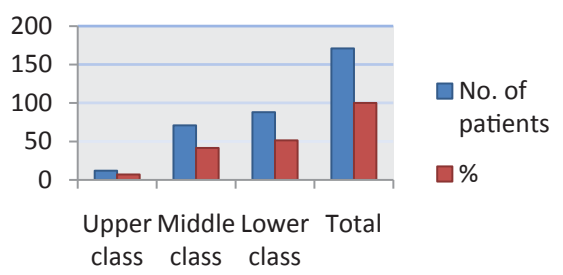

Figure 8: Socio-economic (SE) status of victims of OP poisoning

\begin{tabular}{|l|c|c|}
\hline OP compounds & No. of patients & $\%$ \\
\hline Methyl parathion (Metacid) & 89 & 52.05 \\
\hline Malathion & 22 & 12.87 \\
\hline Dichlorovos (Nuvan, Doom) & 30 & 17.54 \\
\hline Baygon spray & 12 & 7.02 \\
\hline Unknown & 18 & 10.53 \\
\hline Total & 171 & 100 \\
\hline
\end{tabular}

Table 9: Types of different OP compounds administered. 
Citation: Mishra A, Shukla SK, Yadav MK, Gupta AK (2012) Epidemiological Study of Medicolegal Organophosphorus Poisoning in Central Region of Nepal. J Forensic Res 3:167. doi:10.4172/2157-7145.1000167

Page 4 of 5

problem. Females are the main working mass in the Nepalese society and face more stress during daily activities in comparative male. So, they use OP compounds as suicidal purposes because it is available

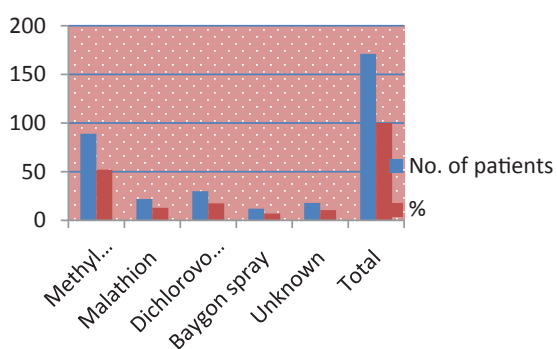

Figure 9: Types of different OP compounds administered.

\begin{tabular}{|c|c|c|}
\hline Reason & No. of victims & $\%$ \\
\hline Financial & 48 & 28.07 \\
\hline Domestic & 50 & 29.24 \\
\hline Failure in love & 14 & 8.19 \\
\hline Exam phobia & 12 & 7.02 \\
\hline Unspecified & 47 & 27.49 \\
\hline Total & 171 & 100 \\
\hline
\end{tabular}

Table 10: Reason of administration of OP compounds.

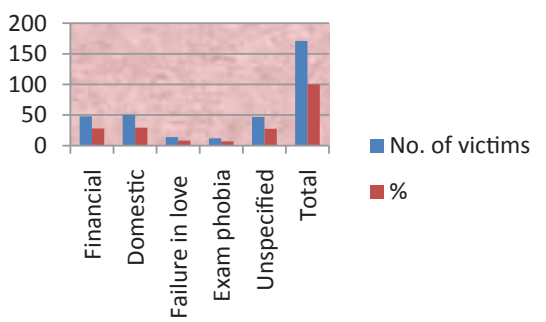

Figure 10: Reason of administration of OP compounds.

\begin{tabular}{|c|c|c|c|c|c|c|c|}
\hline Quantity & OP compounds & $\begin{array}{l}\text { No. of } \\
\text { died } \\
\text { victims }\end{array}$ & $\%$ & $\begin{array}{l}\text { No. of } \\
\text { recovered } \\
\text { patients }\end{array}$ & $\%$ & Total & $\%$ \\
\hline$<10 \mathrm{ml}$ & $\begin{array}{l}\text { Methyl parathion, } \\
\text { DDVP, Baygon spray }\end{array}$ & 1 & 0.58 & 14 & 8.19 & 15 & 8.77 \\
\hline $11-50 \mathrm{ml}$ & $\begin{array}{l}\text { Methyl parathion, } \\
\text { DDVP, Baygon spray }\end{array}$ & 6 & 3.51 & 55 & 32.16 & 61 & 35.67 \\
\hline $\begin{array}{l}51-100 \\
\mathrm{ml}\end{array}$ & $\begin{array}{l}\text { Methyl parathion, } \\
\text { DDVP, Malathion, } \\
\text { Baygon spray, etc. }\end{array}$ & 15 & 8.77 & 45 & 26.32 & 60 & 35.09 \\
\hline$>101 \mathrm{ml}$ & $\begin{array}{l}\text { Methyl parathion, } \\
\text { DDVP, Malathion, } \\
\text { etc. }\end{array}$ & 10 & 5.85 & 25 & 14.62 & 35 & 20.47 \\
\hline Total & & 32 & 18.71 & 139 & 81.29 & 171 & 100 \\
\hline
\end{tabular}

Table 11: Quantity of poison consumed and outcome of OP poisoning cases.

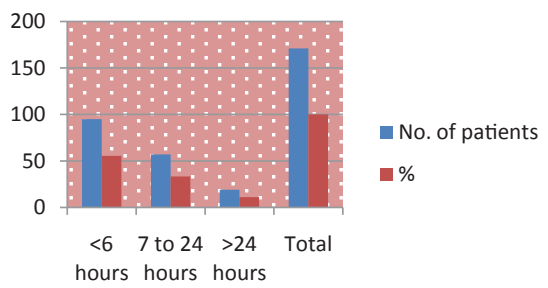

Figure 11: Time interval between consumption of OP compounds and hospital admission.

\begin{tabular}{|c|c|c|}
\hline Time interval & No. of patients & $\%$ \\
\hline$<\mathbf{6}$ hours & 95 & 55.56 \\
\hline $\mathbf{7}$ to $\mathbf{2 4}$ hours & 57 & 33.33 \\
\hline$>\mathbf{2 4}$ hours & 19 & 11.11 \\
\hline Total & 171 & 100 \\
\hline
\end{tabular}

Table 12: Time interval between consumption of OP compounds and hospita admission.
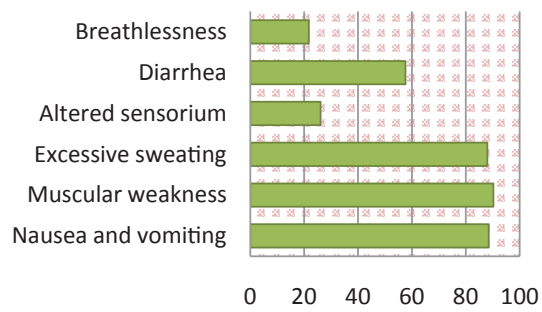

$\square \%$

Figure 12: Common clinical features amongst victims of OP poisoning.

\begin{tabular}{|c|c|}
\hline Clinical features & $\%$ \\
\hline Nausea and vomiting & 88.50 \\
\hline Muscular weakness & 90.23 \\
\hline Excessive sweating & 88.00 \\
\hline Altered sensorium & 26.08 \\
\hline Diarrhea & 57.60 \\
\hline Breathlessness & 21.70 \\
\hline
\end{tabular}

Table 13: Common clinical features amongst victims of OP poisoning.

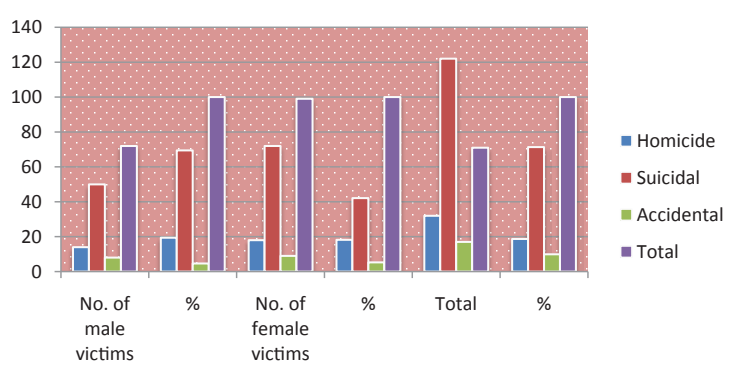

Figure 13: Manner of OP poisoning Cases with Sex distribution.

\begin{tabular}{|c|c|c|c|c|c|c|}
\hline $\begin{array}{c}\text { Manner of } \\
\text { death }\end{array}$ & $\begin{array}{c}\text { No. of male } \\
\text { victims }\end{array}$ & $\%$ & No. of female victims & $\%$ & Total & $\%$ \\
\hline Homicide & 14 & 19.44 & 18 & 18.18 & 32 & 18.71 \\
\hline Suicidal & 50 & 69.44 & 72 & 42.10 & 122 & 71.35 \\
\hline Accidental & 8 & 4.68 & 9 & 5.26 & 17 & 9.94 \\
\hline Total & 72 & 100 & 99 & 100 & 71 & 100 \\
\hline
\end{tabular}

Table 14: Manner of OP poisoning Cases with Sex distribution.

they use OP compounds as suicidal purposes because it is available in common household. Patient with intentional OP poisoning must undergo psychiatric consultation during their stay in the hospital for the treatment of poisoning. This will minimize the risk of next attempt of self harm. As Nepal is country of natural resources and field of cultivation most people are below poverty line. Farmers have been risk group by occupation, they have use OP pesticides during cultivation and there is no restriction on its use.

Hence strict rules must be followed regarding sale of pesticides mainly in adolescent. The pesticides must be sold in the presence 
Citation: Mishra A, Shukla SK, Yadav MK, Gupta AK (2012) Epidemiological Study of Medicolegal Organophosphorus Poisoning in Central Region of Nepal. J Forensic Res 3:167. doi:10.4172/2157-7145.1000167

Page 5 of 5

of a witness who should be known to the client. Many accidental OP poisoning cases occurs due unawareness of proper use of these pesticides. So, proper guidelines and precautions are necessary to handle these pesticides.

\section{Acknowledgements}

The author would like to thank Prof. Dr. L. Sharma, Principal and Chief Medical Superintendent, Prof. Dr. A. N. Thakur, Chairman, Institutional Research Committee, NMCTH and Hospital Superintendent Dr. Chaurasia, NSRH, Birgunj, Nepal for their co-operation in this research work.

\section{References}

1. Bowls BJ, Freeman JM Jr, Luna JA, Meggs WJ (2003) Oral treatment of organophosphate poisoning in mice. Acad Emerg Med 10: 286-288.

2. Eddleston M, Buckley NA, Checketts $H$, Senarathna L, Mohamed F, et al. (2004) Speed of initial atropinisation in significant organophosphorus pesticide poisoning--a systematic comparison of recommended regimens. J Toxicol Clin Toxicol 42: 865-875

3. Karalliedde L, Eddleston M, Murray V (2001) The global picture of organophosphate poisoning. Organophosphates and health. Imperial press London: 432-471.

4. Paudyal BP (2005) Poisoning : pattern and profile of admitted cases in a hospital in central Nepal. JNMA J Nepal Med Assoc 44: 92-96.

5. Kafle KK, Gyawali KK(1992) Organophsphorus- Commonest Poisoning Agent. J Inst Med 14: 228-233

6. Prasad PN, Karki P (1997) Poisoning cases of TUTH emergency; a one-year review. J Inst Med 19: 18-24.

7. Ghimire RH, Sharma SP, Pandey KR (1990) A Retrospective Study of the Changing Trends of Poisoning Cases at Tribhuvan University Teaching Hospital, Nepal Between 1990-1992 and 2000-2002. J NHRC.

8. Subedi BK(1990) A Retrospective Study of Poisoning Cases at Bir Hospital, Nepal. J Inst Med 12: 296-302.

9. Pokhrel N, Gurung CK (1987) A Study of Poison Cases Recorded in Bir Hospital Over four Years. J Inst Med 29-34.

10. Rauniyar GP, Das BP, Naga Rani MA, Gupta MP and Karki BMS (1999) Retrospective Analysis of Profile of Acute Poisoning Cases in a Tertiary Care Hospital in Eastern Nepal: A Four-Year Database from 1994 to 1997. J Nep Med Assoc 38: 23-28.

11. Pathak UN, Chhetri PK, Dhungel S, Chokhani r, Devkota K, et al. (2001) Retrospective Study of Poisoning cases admitted in Nepal Medical College Teaching Hospital. Nep Med Col j 3: 101-105.
12. Murray CJL, Lopez AD (1996) The global burden of disease: a comprehensive assessment of mortality and disability from diseases, injuries and risk factors in 1990 and projected to 2020. (Global burden of disease and injury series. Volume I) Cambridge MA. Harvard School of Public Health.

13. Murray CJL, Lopez AD (1997) Global burden of disease study- Summary. Lancet 349: 1269-1276.

14. Murray CJL, Lopez AD (1996) Global Health statistics. A compendium of incidence, prevalence and mortality estimates for over 200 condition (Global burden of disease and injury series. volume II) Cambridge MA, Harward School of Public Health and WHO

15. Yusuf HR, Akhter HH, Rahman MH, Chowdhury ME, Rochat RW (2000) Injury related deaths among women aged 10-50 years in Bangladesh, 1996-97. Lancet 355: 1220-1224.

16. Jeyaratnam J (1990) Acute pesticide poisoning: a major global health problem World Health Stat Q 43: 139-144.

17. Karalliedde L, Eddleston M, Murray V. Epidemiology of organophosphate insecticide poisoning In: Karalliedde L, Mars T, Feldman F, Henry JA (eds) Organophosphate pesticides and Human health. London: Imperial College ; in press.

18. Unnikrishnan B, Singh B, Rajeev A (2005) Trends of acute poisoning in south Karnataka. Kathmandu Univ Med J (KUMJ) 3: 149-154.

19. Paudyal BP (2008) Organophosphorus poisoning. JNMA J Nepal Med Assoc 47: 251-258.

20. Kar SM, Timsinha S, Agrawal P (2010) An Epidemiological study of Organophosphorus Poisoning at Manipal Teaching Hospital, Phokhara, Nepal. JIAFM. 32: 108-109.

21. Bhattarai MD, Singh DL, Chalise BS, Koirala P (2006) A case report and overview of organophosphate (OP) poisoning. Kathmandu Univ Med J (KUMJ) 4: 100-104.

22. Karki P, Ansari JA, Bhandary S, Koirala S (2004) Cardiac and electrocardiographical manifestations of acute organophosphate poisoning Singapore Med J 45: 385-389.

23. Joshi S, Biswas B, Malla G. Management of Organophosphorus Poisoning Update in Anesthesia.

24. Karki P, Hansdak SG, Bhandari S, Shukla A, Koirala S (2001) A clinicoepidemiological study of organophosphorus poisoning at a rural-based teaching hospital in eastern Nepal. Trop Doct 31: 32-34.

25. Bhattarai N, Rauniyar A, Chaudhary D, Jaiswal S, Banthia P, et al. (2006) Patterns of organophosphorous poisoning attending a teaching hospital. JNMA J Nepal Med Assoc 45: 228-232. 